\title{
A Rapid and Efficient Plant Regeneration Protocol using Leaves and Stems with Buds of Euphorbia pulcherrima Willd. ex Klotzsch (Euphorbiaceae)
}

\author{
L.W. Qiu, G.Y. Huang, G.Y. Zhang, H. Li, M.X. Hu, J.H. Wu, H.Y. Chen
}

10.18805/ag.DF-5441

\begin{abstract}
Background: Euphorbia pulcherrima is highly ornamental value of poinsettia flower, which posses colorful bracts and low temperature resistant leave. Its embryos or adventitious buds were cultivated mainly from stems, petioles and tender buds. The cultivation of seedlings is studied firstly for improving the quality of Poinsettia.

Methods: A rapid and reproducible regeneration system of leaves and stems with buds has been established. There is a comparative analysis of the results of tissue culture of different varieties of Poinsettia.

Result: The best medium component of hormones about leaf callus of poinsettia inducing cluster buds formation comprise 6-BA 1.0 $\mathrm{mg} / \mathrm{L}, \mathrm{KT} 0.4 \mathrm{mg} / \mathrm{L}, \mathrm{NAA} 0.1 \mathrm{mg} / \mathrm{L}$ and 2,4-D $0.05 \mathrm{mg} / \mathrm{L}$. Its medium component inducing cluster buds proliferation include 6-BA 1.2 $\mathrm{mg} / \mathrm{L}$ and NAA $0.05 \mathrm{mg} / \mathrm{L}$. The medium component about stem with bud inducing cluster buds to germinate comprise 6-BA $1.5 \mathrm{mg} / \mathrm{L}$ and NAA $0.1 \mathrm{mg} / \mathrm{L}$. Its medium component inducing cluster buds proliferation include 6-BA $1.0 \mathrm{mg} / \mathrm{L}$ and NAA $0.05 \mathrm{mg} / \mathrm{L}$. The different hormones and different addition level of $A c$ have effect on the length of the root and quantity of the first level root and the second level root.
\end{abstract}

Key words: Cluster buds, Organogenesis, Poinsettia (Euphorbia pucherima), Plant regeneration.

\section{INTRODUCTION}

Poinsettia Euphorbia pulcherrima Willd. ex Klotzsch belongs to Euphorbia Linn., Euphorbiaceae Juss. (Ma and Michael, 2000), which posses some typical characteristics including $30 \sim 50 \mathrm{~cm}$ of the plant height, compact planttype, strong branches, numerous buds, big and colorful bracts and the powerful low temperature resistance as well as not easy-falling leaves (Jiao 2001). It is highly ornamental value of the upmarket pot flower, which bracts begin to change color in December and colorful flowers bloom during the large festival.

The propagation of poinsettia is mainly through tissue culture, which has been used in production since the early 1970s (Nataraj 1975). Its embryos or adventitious buds were cultivated mainly from poinsettia stems, petioles and tender buds (Grotkass et al., 1995). The cultivation of seedlings is studied firstly for improving the quality of Poinsettia (Vilperte et al., 2019), thus we have established regeneration system of leaves and stem with bud. The tissue culture and rapid reproduction research of poinsettia play a key role in exogenous hormone of plant growth regulators (Cheng et al., 2016) and this study has involved the ratio of auxin and cytokinin in exogenous hormones to comprehensive experiments. There is a comparative analysis of the results of tissue culture of different varieties of Poinsettia, and how to reduce costs and simplify tissue culture in the use of exogenous hormones for rapid propagation of poinsettia (Dole and Wilkins, 1992; Horn et al., 2014). The vegetative propagation experiment and establishment research of
China Three Gorges Corporation, Yangtze River Rare Plant Research Institute, Yichang-443000, China.

Corresponding Author: G.Y. Huang, China Three Gorges Corporation, Yangtze River Rare Plant Research Institute, Yichang443000, China. Email: huang_guiyun@ctg.com.cn

How to cite this article: Qiu., L.W., Huang, G.Y., Zhang, G.Y., Li, H., Hu, M.X., J.H. and Chen, H.Y. (2022). A Rapid and Efficient Plant Regeneration Protocol using Leaves and Stems with Buds of Euphorbia pulcherrima Willd. ex Klotzsch (Euphorbiaceae). Agricultural Science Digest. DOI: 10.18805/ag.DF-5441.

Submitted: 01-07-2021 Accepted: 01-11-2021 Online: 25-01-2022

poinsettia have strong theoretical value and practical significance.

\section{MATERIALS AND METHODS}

This experiment was carried out in the Tissue Culture Laboratory of Yangtze River Rare Plant Research Institute, China Three Gorges Corporation from 2018-3 to 2020-10. 6-BA (6-Benzyladenine), KT(Kinetin), NAA (1-Naphthaleneacetic acid), 2, 4-D (2, 4-Dichlorophenoxyacetic acid) four-factor and three-level (Table 1) $\mathrm{L}_{9}\left(3^{4}\right)$ coaxial experiment was designed and each treatment was 10 bottles, with each bottle was 2 callus mass of $0.8 \sim 1 \mathrm{~cm}^{2}$, repeated 3 times. After 30 days, the number of induced cluster buds and the length of buds were observed and the number of buds were counted. 
The experiment used 6-BA, different auxin types and different concentrations of $\mathrm{L}_{8}\left(4 \times 2^{3}\right)$ mixed orthogonal experimental design (Table 2) and a total of 8 treatments. The single buds were respectively inoculated on the medium, each treatment was 10 bottles, each bottle had 2 single buds, and repeated 3 times. After 30 days of inoculation, the number of effective, the length of buds and the proliferation rate were calculated.

Using a two-factor completely random design, the differentiated cluster buds were divided into 3 levels, according to the height of the seedlings (The height of the first seedling is $1.2 \sim 1.6 \mathrm{~cm}$, the height of the second seedling is $0.8 \sim 1.2 \mathrm{~cm}$ and the third level is $0.4 \sim 0.8 \mathrm{~cm}$ ). The method of adding or not adding Ac during the culture process was carried out in a total of 6 treatments, each treatment was 10 bottles and each bottle was inoculated with 2 ex-plants, repeated 3 times. Respectively, they were inoculated in Murashige and Skoog medium (MS + Sucrose: $30 \mathrm{~g} / \mathrm{L}+$ Agar: $6.0 \mathrm{~g} / \mathrm{L}$ ) for strong seedling culture. The seedling height, inter-nodes, stem thickness and leaf color after 30 days.

Table 1: $\mathrm{L}_{9}\left(3^{4}\right)$ orthogonal table.

\begin{tabular}{llllc}
\hline No. & $6-B A$ & KT & NAA & $2,4-\mathrm{D}$ \\
\hline $\mathrm{P}_{1}$ & 0.5 & 0 & 0.1 & 0 \\
$\mathrm{P}_{2}$ & 0.5 & 0.2 & 0.2 & 0.05 \\
$\mathrm{P}_{3}$ & 0.5 & 0.4 & 0.3 & 0.1 \\
$\mathrm{P}_{4}$ & 1 & 0 & 0.2 & 0.1 \\
$\mathrm{P}_{5}$ & 1 & 0.2 & 0.3 & 0 \\
$\mathrm{P}_{6}$ & 1 & 0.4 & 0.1 & 0.05 \\
$\mathrm{P}_{7}$ & 1.5 & 0 & 0.3 & 0.05 \\
$\mathrm{P}_{8}$ & 1.5 & 0.2 & 0.1 & 0.1 \\
$\mathrm{P}_{9}$ & 1.5 & 0.4 & 0.2 & 0 \\
\hline
\end{tabular}

Table 2: $\mathrm{L}_{8}\left(4 \times 2^{3}\right)$ orthogonal table of cluster buds reproduction.

\begin{tabular}{lcccccc}
\hline \multirow{2}{*}{ No. } & \multicolumn{3}{c}{ Leaves } & \multicolumn{4}{c}{ Stems with buds } \\
\cline { 2 - 7 } & 6 6-BA & $2,4-\mathrm{D}$ & NAA & $6-\mathrm{BA}$ & $2,4-\mathrm{D}$ & NAA \\
\hline $\mathrm{P}_{1}$ & 0.8 & 0.1 & 0.1 & 0.6 & 0.05 & 0.05 \\
$\mathrm{P}_{2}$ & 0.8 & 0.15 & 0.15 & 0.6 & 0.1 & 1 \\
$\mathrm{P}_{3}$ & 1 & 0.1 & 0.1 & 0.8 & 0.05 & 0.05 \\
$\mathrm{P}_{4}$ & 1 & 0.15 & 0.15 & 0.8 & 0.1 & 1 \\
$\mathrm{P}_{5}$ & 1.2 & 0.1 & 0.15 & 1 & 0.05 & 1 \\
$\mathrm{P}_{6}$ & 1.2 & 0.15 & 0.1 & 1 & 0.1 & 0.05 \\
$\mathrm{P}_{7}$ & 1.4 & 0.1 & 0.15 & 1.2 & 0.05 & 1 \\
$\mathrm{P}_{8}$ & 1.4 & 0.15 & 0.1 & 1.2 & 0.1 & 0.05 \\
\hline
\end{tabular}

Table 3: $L_{4}\left(2^{3}\right)$ orthogonal table.

\begin{tabular}{lcccccc}
\hline \multirow{2}{*}{ No. } & \multicolumn{3}{c}{ Leaves } & \multicolumn{3}{c}{ Stems with buds } \\
\cline { 2 - 7 } & IBA & NAA & $6-B A$ & IBA & $6-B A$ & Ac \\
\hline $\mathrm{P}_{1}$ & 0.2 & 0.5 & 0 & 0.8 & 0.1 & 100 \\
$\mathrm{P}_{2}$ & 0.2 & 1 & 0.1 & 0.8 & 0.2 & 200 \\
$\mathrm{P}_{3}$ & 0.8 & 0.5 & 0.1 & 1.2 & 0.1 & 200 \\
$\mathrm{P}_{4}$ & 0.8 & 1 & 0 & 1.2 & 0.2 & 100 \\
\hline
\end{tabular}

6-BA, IBA (Indolebutyric acid), NAA or Ac (Activated carbon) three-factor and two-level $\mathrm{L}_{4}\left(2^{3}\right)$ coaxial experiment was designed (Table 3). A total of 4 treatments, 10 bottles for each treatment, 2 for each bottle, we repeated 3 times. The root length, seedling height, and number of first-level roots and second-level roots were observed after 30 days.

The data obtained were statistically analyzed by SPSS (Statistical Product and Service Solutions) software package which the least significant difference test set at a $5 \%$ level of significance (Du and Pijut, 2008). The percentage data were first transformed by arc-sine and then analyzed by variance and multiple comparisons.

\section{RESULTS AND DISCUSSION}

\section{Leaves regeneration}

The different hormones have effect on leaf callus induction with the frequency and size of callus formation as the main index and the color and quality of callus as a reference. Finally, the results have revealed that the best medium component about leaves of poinsettia inducing callus formation contain MS, NAA $1.0 \mathrm{mg} / \mathrm{L}, 6-\mathrm{BA} 0.1 \mathrm{mg} / \mathrm{L}$, sucrose $30 \mathrm{mg} / \mathrm{L}$, agar $6.0 \mathrm{~g} / \mathrm{L}$, and its $\mathrm{PH}$ value is 5.8 (Fig 1a; Table 4). The different hormones have influence on callus inducing cluster buds formation with the germination rate as the main index and the quantity and length of buds and the better growth vigor as references, which have indicated that the best medium component of hormones about leaf callus inducing cluster buds formation comprise 6-BA $1.0 \mathrm{mg} / \mathrm{L}$, $\mathrm{KT} 0.4 \mathrm{mg} / \mathrm{L}$, NAA $0.1 \mathrm{mg} / \mathrm{L}$ and 2, 4-D $0.05 \mathrm{mg} / \mathrm{L}$. The different 6-BA concentration and the different kind of auxin have impact on the cluster buds proliferation with proliferation rate as the main index, referencing the quantity and length of effective buds and better growth vigor. In conclusion, the medium component about leaf callus inducing cluster buds proliferation include 6-BA $1.2 \mathrm{mg} / \mathrm{L}$ and NAA $0.05 \mathrm{mg} / \mathrm{L}$ (Fig 1b; Table 5). The fractional culture of different budling and Ac addition have effect on strong seedling cultivation of cluster buds (Firoozabady and Gutterson, 2003). The different hormones have influence on rooting with length of the root and quantity of the first level root and the second level root deemed to the main index, referencing the height of seedling and the better growth vigor. Lastly, the medium component about leaf inducing cluster buds to take root contain IBA $0.8 \mathrm{mg} / \mathrm{L}$, NAA $0.5 \mathrm{mg} / \mathrm{L}$ and 6-BA 0.1mg/L (Fig 1c; Table 6).

\section{Stems with buds regeneration}

The different concentrations of 6-BA and NAA have influence on inducing cluster buds of stem with bud to germinate (Jiao et al., 2017). The medium component about stem with bud inducing cluster buds to germinate comprise 6-BA $1.5 \mathrm{mg} / \mathrm{L}$ and NAA $0.1 \mathrm{mg} / \mathrm{L}$ (Fig 1d). The different 6-BA concentration and the different kind of auxin have effect on the cluster buds proliferation, which the medium component inducing cluster buds proliferation include $6-\mathrm{BA} 1.0 \mathrm{mg} / \mathrm{L}$ and NAA $0.05 \mathrm{mg} / \mathrm{L}$ (Fig 1e; Table 5). The different addition level of 

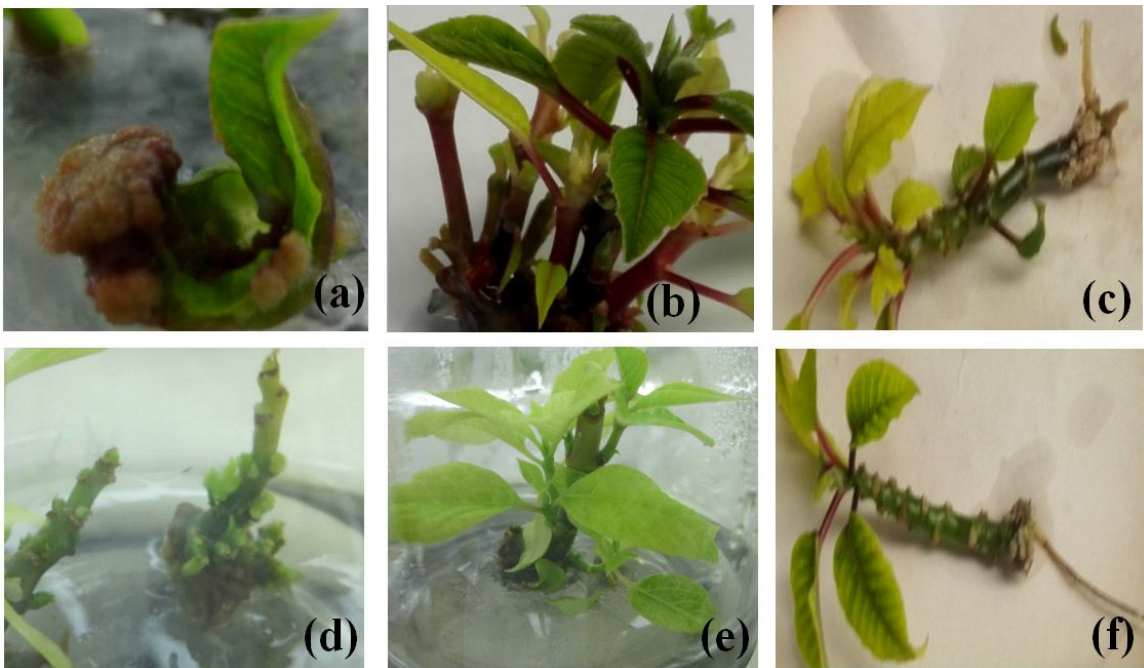

Fig 1: Establishment of poinsettia leaf and stem with buds regeneration (a) Leaf callus induction; (b) Cluster buds proliferation; (c) Callus rooting at the base of cluster buds; (d) Bud enlargement; (e) Bud germination and vigorous growth; (f) Clustering callus rooting at bud base.

Table 4: Multiple comparison of callus inducting cluster buds between combinations affected by the different hormone.

\begin{tabular}{|c|c|c|c|c|c|c|c|}
\hline Leaves & $\begin{array}{c}\text { 6-BA } \\
(\mathrm{mg} / \mathrm{L})\end{array}$ & $\begin{array}{c}\mathrm{KT} \\
(\mathrm{mg} / \mathrm{L})\end{array}$ & $\begin{array}{l}\text { NAA } \\
(\mathrm{mg} / \mathrm{L})\end{array}$ & $\begin{array}{l}2,4-D \\
(\mathrm{mg} / \mathrm{L})\end{array}$ & $\begin{array}{l}\text { Germination } \\
\text { rate }(\%)\end{array}$ & $\begin{array}{c}\text { Number of } \\
\text { buds }\end{array}$ & $\begin{array}{l}\text { Bud length } \\
\qquad(\mathrm{cm})\end{array}$ \\
\hline $\mathrm{P}_{1}$ & $1(0.5)$ & $1(0)$ & $1(0.1)$ & $1(0)$ & $30.0 \pm 0.05 \mathrm{Bd}$ & $15.7 \pm 1.5 \mathrm{Ff}$ & $0.7 \pm 0.2 \mathrm{Gf}$ \\
\hline $\mathrm{P}_{2}$ & $1(0.5)$ & $2(0.2)$ & $2(0.2)$ & $2(0.05)$ & $31.7 \pm 0.07 \mathrm{Bd}$ & 16.7 $\pm 1.5 \mathrm{EFf}$ & $0.7 \pm 0.1 \mathrm{Gf}$ \\
\hline $\mathrm{P}_{3}$ & $1(0.5)$ & $3(0.4)$ & $3(0.3)$ & $3(0.1)$ & $40.0 \pm 0.10 \mathrm{Bdc}$ & $20.7 \pm 2.0 \mathrm{Ee}$ & $1.0 \pm 0.1 \mathrm{FGe}$ \\
\hline $\mathrm{P}_{4}$ & $2(1.0)$ & $1(0)$ & $2(0.2)$ & $3(0.1)$ & $46.7 \pm 0.07 \mathrm{Bc}$ & $35.3 \pm 2.5 \mathrm{Cc}$ & 1.6 6 0.1DEd \\
\hline$P_{5}$ & $2(1.0)$ & $2(0.2)$ & $3(0.3)$ & $1(0)$ & $50.0 \pm 0.05 \mathrm{Bc}$ & $32.7 \pm 1.5 \mathrm{Cc}$ & $2.2 \pm 0.2 \mathrm{Cc}$ \\
\hline $\mathrm{P}_{6}$ & $2(1.0)$ & $3(0.4)$ & $1(0.1)$ & $2(0.05)$ & $83.3 \pm 0.07 \mathrm{Aa}$ & $51.3 \pm 1.5 \mathrm{Aa}$ & $3.3 \pm 0.1 \mathrm{Aa}$ \\
\hline$P_{7}$ & $3(1.5)$ & $1(0)$ & $3(0.3)$ & $2(0.05)$ & $46.7 \pm 0.07 \mathrm{Bc}$ & $32.7 \pm 1.5 \mathrm{Cc}$ & $1.8 \pm 0.1 \mathrm{DCd}$ \\
\hline $\mathrm{P}_{8}$ & $3(1.5)$ & $2(0.2)$ & $1(0.1)$ & $3(0.1)$ & $71.7 \pm 0.07 \mathrm{Ab}$ & $43.3 \pm 2.0 \mathrm{Bb}$ & $2.6 \pm 0.1 \mathrm{Bb}$ \\
\hline $\mathrm{P}_{9}$ & $3(1.5)$ & $3(0.4)$ & $2(0.2)$ & $1(0)$ & $43.3 \pm 0.07 \mathrm{Bdc}$ & $27.0 \pm 2.6 \mathrm{Dd}$ & $1.3 \pm 0.1 \mathrm{EFe}$ \\
\hline
\end{tabular}

Table 5: Multiple comparison of cluster buds reproduction between combinations.

\begin{tabular}{|c|c|c|c|c|c|c|}
\hline Leaves & $\begin{array}{c}1 \\
(6-B A)\end{array}$ & $\begin{array}{c}2 \\
\text { (type) }\end{array}$ & $\begin{array}{c}3 \\
(\mathrm{mg} / \mathrm{L})\end{array}$ & $\begin{array}{c}\text { Proliferation } \\
\text { rate }(\%)\end{array}$ & $\begin{array}{c}\text { Effective bud } \\
\text { number }\end{array}$ & $\begin{array}{l}\text { Bud length } \\
\qquad(\mathrm{cm})\end{array}$ \\
\hline$\overline{P_{1}}$ & $1(0.8)$ & $1(2,4-D)$ & $1(0.05)$ & $33.3 \pm 0.12 \mathrm{Bc}$ & $1.0 \pm 0.57 \mathrm{Ab}$ & $1.41 \mathrm{Ab}$ \\
\hline $\mathrm{P}_{2}$ & $1(0.8)$ & 2(NAA) & $2(0.1)$ & $53.3 \pm 0.06 \mathrm{Bb}$ & $2.0 \pm 0.51 \mathrm{Ab}$ & $1.65 \mathrm{Ab}$ \\
\hline $\mathrm{P}_{3}$ & $2(1.0)$ & $1(2,4-D)$ & $1(0.05)$ & $50.0 \pm 0.1 \mathrm{Bbc}$ & $2.0 \pm 0.47 \mathrm{Ab}$ & $1.64 \mathrm{Ab}$ \\
\hline $\mathrm{P}_{4}$ & $2(1.0)$ & 2(NAA) & $2(0.1)$ & $60.0 \pm 0.17 \mathrm{Bb}$ & $2.0 \pm 0.36 \mathrm{Ab}$ & $1.55 \mathrm{Ab}$ \\
\hline$P_{5}$ & $3(1.2)$ & $1(2,4-D)$ & $2(0.1)$ & $60.0 \pm 0.1 \mathrm{Bb}$ & $4.0 \pm 0.06 \mathrm{Aa}$ & $2.68 \mathrm{Aa}$ \\
\hline $\mathrm{P}_{6}$ & $3(1.2)$ & 2 (NAA) & $1(0.05)$ & $93.3 \pm 0.06 \mathrm{Aa}$ & $5.0 \pm 0.30 \mathrm{Aa}$ & $3.10 \mathrm{Aa}$ \\
\hline $\mathrm{P}_{7}$ & $4(1.4)$ & $1(2,4-D)$ & $2(0.1)$ & $60.0 \pm 0.1 \mathrm{Bb}$ & $2.0 \pm 0.48 \mathrm{Ab}$ & $1.29 \mathrm{Ab}$ \\
\hline $\mathrm{P}_{8}$ & $4(1.4)$ & 2(NAA) & $1(0.05)$ & $53.3 \pm 0.16 \mathrm{Bb}$ & $2.0 \pm 0.31 \mathrm{Ab}$ & $1.15 \mathrm{Ab}$ \\
\hline \multicolumn{7}{|c|}{ Stems with buds } \\
\hline$P_{1}$ & $1(0.6)$ & $1(2,4-D)$ & $1(0.05)$ & $33.3 \pm 0.12 \mathrm{Bc}$ & $3.3 \pm 0.57 \mathrm{Dd}$ & $1.0 \pm 0.07 \mathrm{C}$ \\
\hline $\mathrm{P}_{2}$ & $1(0.6)$ & 2 (NAA) & $2(0.1)$ & $53.3 \pm 0.06 \mathrm{Bb}$ & $3.3 \pm 0.57 \mathrm{Dd}$ & $1.5 \pm 0.10 \mathrm{~B}$ \\
\hline $\mathrm{P}_{3}$ & $2(0.8)$ & $1(2,4-D)$ & $1(0.05)$ & $50.0 \pm 0.1 \mathrm{Bb}$ & $6.3 \pm 0.57 \mathrm{Cc}$ & $1.7 \pm 0.15 \mathrm{~B}$ \\
\hline $\mathrm{P}_{4}$ & $2(0.8)$ & 2(NAA) & $2(0.1)$ & $60.0 \pm 0.17 \mathrm{Bb}$ & $10.0 \pm 1.0 \mathrm{Bb}$ & $1.8 \pm 0.20 \mathrm{~B}$ \\
\hline $\mathrm{P}_{5}$ & $3(1.0)$ & $1(2,4-D)$ & $2(0.1)$ & $60.0 \pm 0.1 \mathrm{Bb}$ & $7.3 \pm 0.57 \mathrm{Cc}$ & $1.7 \pm 0.24 \mathrm{~B}$ \\
\hline $\mathrm{P}_{6}$ & $3(1.0)$ & 2(NAA) & $1(0.05)$ & $80.0 \pm 0.1 \mathrm{Aa}$ & $13.7 \pm 0.57 \mathrm{Aa}$ & $2.6 \pm 0.18 \mathrm{~A}$ \\
\hline$P_{7}$ & $4(1.2)$ & $1(2,4-D)$ & $2(0.1)$ & $60.0 \pm 0.1 \mathrm{Bb}$ & $7.7 \pm 0.57 \mathrm{Cc}$ & $1.1 \pm 0.03 \mathrm{C}$ \\
\hline$P_{8}$ & $4(1.2)$ & 2(NAA) & $1(0.05)$ & $53.3 \pm 0.16 \mathrm{Bb}$ & $11.3 \pm 1.57 \mathrm{Bb}$ & $1.7 \pm 0.07 \mathrm{~B}$ \\
\hline
\end{tabular}


A Rapid and Efficient Plant Regeneration Protocol using Leaves and Stems with Buds of [Euphorbia pulcherrima Willd.....

Table 6: Multiple comparison of different hormones impacting rooting between combinations.

\begin{tabular}{lccccccc}
\hline Leaves & IBA & NAA & $6-\mathrm{BA}$ & $\begin{array}{c}\text { Root length } \\
(\mathrm{cm})\end{array}$ & $\begin{array}{c}\text { Seedling height } \\
(\mathrm{cm})\end{array}$ & $\begin{array}{c}\text { First-level } \\
\text { roots }\end{array}$ & $\begin{array}{c}\text { Second-level } \\
\text { roots }\end{array}$ \\
\hline $\mathrm{P}_{1}$ & $1(0.2)$ & $1(0.5)$ & $1(0)$ & $14.7 \pm 1.4 \mathrm{Cc}$ & $1.9 \pm 0.2 \mathrm{Bc}$ & $1.7 \pm 0.5 \mathrm{Bb}$ & $5.7 \pm 1.5 \mathrm{Bc}$ \\
$\mathrm{P}_{2}$ & $1(0.2)$ & $2(1.0)$ & $2(0.1)$ & $21.0 \pm 1.6 \mathrm{Bb}$ & $2.6 \pm 0.2 \mathrm{ABb}$ & $2.3 \pm 0.5 \mathrm{ABb}$ & $6.7 \pm 1.1 \mathrm{Bbc}$ \\
$\mathrm{P}_{3}$ & $2(0.8)$ & $1(0.5)$ & $2(0.1)$ & $26.9 \pm 2.0 \mathrm{Aa}$ & $3.2 \pm 0.4 \mathrm{Aa}$ & $4.3 \pm 0.5 \mathrm{Aa}$ & $13.0 \pm 1.7 \mathrm{Aa}$ \\
$\mathrm{P}_{4}$ & $2(0.8)$ & $2(1.0)$ & $1(0)$ & $22.3 \pm 2.0 \mathrm{ABb}$ & $2.0 \pm 0.2 \mathrm{Bc}$ & $3.0 \pm 1.0 \mathrm{ABb}$ & $9.7 \pm 2.0 \mathrm{ABb}$ \\
\hline
\end{tabular}

Table 7: Multiple comparison of the different hormones and addition level of activated carbon having influence on rooting between combinations.

\begin{tabular}{lcccccrc}
\hline $\begin{array}{l}\text { Stems with } \\
\text { buds }\end{array}$ & IBA & 6 -BA & Ac & $\begin{array}{c}\text { Root length } \\
(\mathrm{cm})\end{array}$ & $\begin{array}{c}\text { Seedling height } \\
(\mathrm{cm})\end{array}$ & $\begin{array}{c}\text { First-level } \\
\text { roots }\end{array}$ & $\begin{array}{c}\text { Second-level } \\
\text { roots }\end{array}$ \\
\hline $\mathrm{P}_{1}$ & $1(0.8)$ & $1(0.1)$ & $1(100)$ & $35.4 \pm 0.85 \mathrm{~B}$ & $1.9 \pm 0.15 \mathrm{Cc}$ & $1.7 \pm 0.57 \mathrm{Cc}$ & $11.3 \pm 0.57 \mathrm{Cc}$ \\
$\mathrm{P}_{2}$ & $1(0.8)$ & $2(0.2)$ & $2(200)$ & $22.7 \pm 1.44 \mathrm{C}$ & $2.2 \pm 0.20 \mathrm{BCbc}$ & $2.3 \pm 0.57 \mathrm{BCbc}$ & $16.3 \pm 1.52 \mathrm{Bb}$ \\
$\mathrm{P}_{3}$ & $2(1.2)$ & $1(0.1)$ & $2(200)$ & $43.8 \pm 4.25 \mathrm{~A}$ & $3.5 \pm 0.10 \mathrm{Aa}$ & $5.7 \pm 0.57 \mathrm{Aa}$ & $25.3 \pm 1.52 \mathrm{Aa}$ \\
$\mathrm{P}_{4}$ & $2(1.2)$ & $2(0.2)$ & $1(100)$ & $31.9 \pm 1.40 \mathrm{~B}$ & $2.6 \pm 0.20 \mathrm{Bb}$ & $3.3 \pm 0.57 \mathrm{Bb}$ & $18.3 \pm 1.52 \mathrm{Bb}$ \\
\hline
\end{tabular}

Ac and fractional culture of different budling have influence on strong seedling cultivation of cluster buds. The different hormones and different addition level of Ac have effect on rooting with the length of the root and quantity of the first level root and the second level root deemed to the main index, and the height of seedling and the better growth vigor as references. Lastly, the results have showed that the medium component inducing cluster buds to take root include IBA 1.2 mg/L, 6-BA 0.1 mg/L, Ac 200 mg/L (Fig 1f; Table 7).

The tender leaves which selected as ex-plants can easily induce callus (Grotkass et al., 1995). This experiment found that the callus induction rate of the leaves at the top of the shoots was high, and the callus induction time was about 7 days earlier than that of other leaves. The callus was induced after being cut on the leaves of the Poinsettia, and was easy to grow from the wound with the strong differentiation (Wang et al., 2013; Jantasorn et al., 2021). This experiment found that cutting 2 horizontally along the middle of the main vein of the leaf has a higher rate of producing callus than other parts of the wound. The callus was pale yellow and granular. This callus was more prone to dedifferentiation to produce cluster buds.

In the process of multiplication and cultivation of cluster buds, the appropriate addition of Ac can inhibit the proliferation of a large number of weak buds and play a role in seedlings (Jiao 2001). Combining the proliferation of cluster buds and the amount of Ac, it can not only save the cultivation time, but also reduce the investment and achieve the purpose of reducing costs and increasing efficiency (Mali and Chavan, 2016). In the further study, as the Poinsettia leaves induce the cluster buds to conduct outdoor hydroponic rooting, it is hoped that this will simplify the tissue culture procedure, reduce the indoor culture time and production costs, and enhance the ability of the tissue culture seedlings, which adapt to the external environment and improve the survival rate of tissue cultured seedlings (Cheng et al., 2016; Thakuria et al., 2018).
Poinsettia shoots with buds induce cluster buds. If the culture time is too long, the ex-plants and the medium are prone to produce secretions. And the secretions affect the differentiation, proliferation and growth of the cluster buds (Huang et al., 2014; Kenasa et al., 2021). This experiment found that in the process of cultivating shoots with buds, especially during the transfer process, the clustering buds were easy to flow out of white jelly from the wound after being cut. If the jelly has been absorbed in time, it was easy to cause endophytic infection, which affected the growth of sterile seedlings.

The appropriate addition of Ac can inhibit the proliferation of a large number of weak buds and overcome the growth of endophytic bacteria and adsorb substances that inhibit the growth of seedlings (Moustaka et al., 2018). This is the first report of an efficient plant regeneration protocol for poinsettia through direct organogenesis using ex-plants. Hence, this provides a more efficient basis for the genetic transformation than previously available (Moustaka et al., 2020; Trang et al., 2021).

\section{CONCLUSION}

We have developed a stable and efficient plant regeneration system for Poinsettia using leaves and stem with bud as the original ex-plants. The medium component about leaf of Poinsettia inducing cluster buds to take root contained MS, IBA $0.8 \mathrm{mg} / \mathrm{L}$, NAA $0.5 \mathrm{mg} / \mathrm{L}$, 6-BA $0.1 \mathrm{mg} / \mathrm{L}$, sucrose $30 \mathrm{mg} / \mathrm{L}$, agar $6.0 \mathrm{~g} / \mathrm{L}$ and its $\mathrm{pH}$ value was 5.8 . The best way of stem with bud of Poinsettia inducing strong seedling cultivation of cluster buds was that the optimum height of seedling was the first level budding with $1.2 \sim 1.6 \mathrm{~cm}$. The medium component which $\mathrm{pH}$ value was 5.8 , which contained MS, sucrose $30 \mathrm{mg} / \mathrm{L}$, agar $6.0 \mathrm{~g} / \mathrm{L}$ and Ac 200 $\mathrm{mg} / \mathrm{L}$. The medium component about stem with bud of Poinsettia inducing cluster buds to take root included $M S$, IBA $1.2 \mathrm{mg} / \mathrm{L}, 6-B A 0.1 \mathrm{mg} / \mathrm{L}$, Ac $200 \mathrm{mg} / \mathrm{L}$, sucrose $30 \mathrm{mg} /$ $\mathrm{L}$, agar $6.0 \mathrm{~g} / \mathrm{L}$ and its $\mathrm{pH}$ value was 5.8 . This regeneration 
system provides the necessary basis for genetic transformation procedures and we are currently making progress towards an mediated transformation protocol (Pooja et al., 2021).

\section{Funding}

This work was supported by China Three Gorges Corporation (Grant No. WWKY-2020-0251).

\section{ACKNOWLEDGEMENT}

We thank Dr Weibo Xiang for the assistance with editing of the manuscript and all colleagues in our laboratory for technical assistance. All authors contributed to the study conception and design. Material preparation, data collection and analysis were performed by Meixiang $\mathrm{Hu}$, Jinhua $\mathrm{Wu}$ and Huiyuan Chen. The first draft of the manuscript was written by Hao Li and Liwen Qiu. Guiyun Huang and Guoyu Zhang commented on previous versions of the manuscript.

\section{REFERENCES}

Cheng, C.H., Zang, G.G., Zhao, L.N., Gao, C.S., Tang, Q., Chen, J.H., Guo, X.B., Peng, D.X., Su, J.G. (2016). A rapid shoot regeneration protocol from the cotyledons of hemp (Cannabis sativa L.). Ind Crops Prod. 83: 61-65. DOI: 10.1016/j.indcrop.2015.12.035.

Dole, J.M., Wilkins, H.F. (1992). In vivo charaeterization of a grafttransmissible free-branehing agent in Poinsettia. J. Amer. Soc. Hort. Sci. DOI: 10.21273 JASHS.117.6.972.

Du, N., Pijut, P.M. (2008). Regeneration of plants from Fraxinus pennsylvanica hypocotyls and cotyledons.Sci Hortic.118(1): 74-79. DOI: 10.1016/j.scienta.2008.05.014.

Firoozabady, F., Gutterson, N. (2003). Cost-cHcctivc in vitro pagation methods for pineapple. Cell Biology and Morphogenesis. 21: 844-850. DOI: 10.1007/s00299-003-0577-x.

Grotkass, C., Lieberei, R., Preil, W. (1995). Polyphenoloxidase activity and activation in embryogenic and non embryogenic suspension cultures of Euphorbia pulcherrima. Plant Cell Reports. 14: 428-431. DOI: 10.1007/BF00234048.

Horn, J.W., Xi, Z., Riina, R., Peirson, J.A., Yang, Y., Dorsey, B.L., Wurdack, K.J. (2014). Evolutionary bursts in Euphorbia (Euphorbiaceae) are linked with photosynthetic pathway. Evolution. 68(12): 3485-3504. DOI: 10.1111/evo.12534.

Huang, H., Li, J.C., Yang, K.X., Zhao, X.H., Li, P., Liao, B.Y., Chen, X.Y. (2014). Direct adventitious shoot organogenesis and plant regeneration from cotyledon explants in Neolamarckia cadamba. Plant Biotechnol. 31(2): 115-121. DOI:10.5511/ Plant Biotechnology. 14.0125a

Kenasa, G., Nandeshwar, B.C. and Assefa, F. (2021). In vitro inorganic phosphate solubilization tests of cowpea root nodule bacteria from Ethiopia. Agricultural Science Digest. 41 (Special Issue): 195-198. DOI: 10.18805/ag.D-260.
Jantasorn, A., Pongsupap, P., Oiuphisittraiwat, T. (2021). In vitro Effect of Caesalpinia sappan and Crateva magna Extracts in Enhancing Seed Germination and Seedling Growth of KDML105 Rice Variety. Indian Journal of Agricultural Research. 55(4): 458-462. DOI: 10.18805/IJARe.A-569.

Jiao, H.H. (2001). Study on tissue culture and plant regeneration of Euphorbia Pulcherrima wild. Wuhan:Central China Normal University, College of Life Science.

Jiao, Y., Chen, Y.H., Ma, C.F., Qin, J.J., Nguyen, N.H.T., Liu, D., Gan, H.H., Ding, S. and Luo, Z.B. (2017). Phenylalanine as a nitrogen source induces root growth and nitrogenuse efficiency in Populus canescens. Tree Physiology. 38: 66-82. DOI: 10.1093/treephys/tpx109.

Ma, J.S., Michael, G.G. (2000). Euphorbia L. Flora of China. Beijing: Science Press; St. Louis:Missouri Botanical Garden Press. 11: 163-314.

Mali, A.M., Chavan, N.S. (2016). In vitro rapid regeneration through direct organogenesis and ex-vitro establishment of Cucumis trigonus Roxb.-An underutilized pharmaceutically important cucurbit. Ind Crops Prod. 83: 48-54. DOI: 10.1016/ j.indcrop. 2015.12.036.

Moustaka, J., Panteris, E., Adamakis, I.D.S., Tanou, G., Giannakoula, A., Eleftheriou, E.P., Moustakas, M. (2018). High anthocyanin accumulation in poinsettia leaves is accompanied by thylakoid membrane unstacking, acting as a photoprotective mechanism, to prevent ROS formation. Environ. Exp. Bot. 154: 44-55. DOI: 10.1016/j.envexpbot.2018.01.006.

Moustaka, J., Tanou, G., Giannakoula, A., Adamakis, S.I-D., Panteris, E., Eleftheriou, P.E., Moustakas, M. (2020). Anthocyanin accumulation in poinsettia leaves and its functional role in photo-oxidative stress. Environmental and Experimental Botany. 175. DOI: 10.1016/j.envexpbot.2020.10 4065.

Nataraj, K. (1975). Morphogenesis in embryonal callus of Euphorbia pulcherrima in vitro. Current Sic. 44: 136.

Pooja, A.P. and Ameena, M. (2021). Nutrient and PGR Based Foliar Feeding for Yield Maximization in Pulses: A Review. Agricultural Reviews. 42(1): 32-41. DOI: 10.18805/ag.R-2056.

Thakuria, K., Saud, R.K., Thakuria, C. (2018). Effect of planting dates and nutrient management on double planted late sali rice (Oryza sativa L.) under lowland situation. Agric. Sci. Digest. 38(3): 201-204. DOI: 10.18805/ag.D-4750.

Trang, N.T.Q., Hong, H.T.K., Huong, V.T.M. and Long, D.T. (2021). In vitro Propagation of Red Lotus (Nelumbo nucifera Gaertn) An Aquatic Edible Plant in Vietnam. Agricultural Science Digest. 41 (Special Issue): 129-136. DOI: 10.18805/ag.D-257.

Vilperte, V., Lucaciu, R.C., Halbwirth, H., Boehm, R., Rattei, T., Debener, T. (2019). Hybrid de novo transcriptome assembly of poinsettia Euphorbia pulcherrima Willd. ex Klotsch bracts. BMC Genomics. 20: 900. DOI: 10.1186/s12864019-6247-3.

Wang, H., Petri, C., Burgos, L., Alburquerque, N. (2013). Efficient in vitro shoot regeneration from mature apricot (Prunus armeniaca L.) cotyledons. Sci Hortic. 160: 300-305. DOI: 10.1016/j.scienta.2013.06.013. 